\title{
To whom it may concern
}

The paper "Ecological, morphological and molecular characterization of Kryptoperidinium sp. (Dinophyceae) from two Mediterranean coastal shallow lagoons." by Cecilia Teodora Satta was edited by Elsevier Language Editing Services.

Kind regards,

\section{Elsevier Webshop Support}

